\title{
Inhibition of Cancer Cell Proliferation and Antiradical Effects of Decoction, Hydroalcoholic Extract, and Principal Constituents of Hemidesmus indicus R. Br.
}

\author{
Giancarlo Statti, ${ }^{1}$ Mariangela Marrelli, ${ }^{1}$ Filomena Conforti, ${ }^{1} *$ Antonella Spagnoletti, ${ }^{2}$ \\ Massimo Tacchimi,', Carmela Fimognari, ${ }^{3}$ Eleonora Brognara, ${ }^{2}$ Roberto Gambari, \\ Gianni Sacchetti ${ }^{2}$ and Alessandra Guerrini $i^{2}$

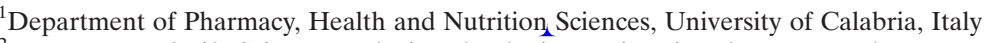 \\ ${ }^{2}$ Department of Life Sciences and Biotechnologies, University of Ferrara, Italy \\ ${ }^{3}$ Department for Life Quality Studies, Alma Mater Studiorum-University of Bologna, Rimini, Italy
}

\begin{abstract}
Indian Sarsaparilla (Hemidesmus indicus R. Br.) is widely used in Indian traditional medicine. In the present work, we explored the effects of decoction, traditional Ayurvedic preparation, and hydroalcoholic extract, a phytocomplex more traditionally studied and commercialized as food supplement in western medicine, from the roots as possible source of chemicals with new functional potential linked to their nutritional uses. The antiproliferative and antioxidant properties were assayed. To test antiproliferative affects, different cancer cell lines, growing both as monolayers (CaCo2, MCF-7, A549, K562, MDA-MB-231, Jurkat, HepG2, and LoVo) and in suspension (K562 and Jurkat) were used. The decoction showed strong activity on HepG2 cells, while the hydroalcoholic extracts were active on HepG2, LoVo, MCF-7, K562, and Jurkat cell lines. Weak inhibition of cancer cell proliferation was observed for the principal constituents of the preparations: 2-hydroxy-4methoxybenzaldehyde, 2-hydroxy-4-methoxybenzoic acid, and 3-hydroxy-4-methoxybenzaldehyde that were tested alone. The antiradical activity was tested with 2,2-diphenyl-1-picrylhydrazyl and 2,2'-azinobis(3-ethylbenzothiazoline-6-sulfonic acid)diammonium salt tests and inhibition of nitric oxide production in lipopolysaccharidestimulated RAW 264.7 macrophages. Interesting result has also been obtained for hydroalcoholic extract regarding genoprotective potential $(58.79 \%$ of inhibition at $37.5 \mu \mathrm{g} / \mathrm{mL})$. Copyright $@ 2015$ John Wiley \& Sons, Ltd.
\end{abstract}

Keywords: Ayurveda; antitumor activity; genoprotective potential; antioxidants; nitric oxide inhibitors.

Abbreviations: DPPH, 2,2-Diphenyl-1-picrylhydrazyl; ABTS, 2,2'-Azinobis(3-ethylbenzothiazoline-6-sulfonic acid)diammonium salt; $\mathrm{CaCo}$, Human colorectal adenocarcinoma cells; MCF-7, Human estrogen receptor (ER)-positive breast adenocarcinoma cells; A549, Human lung carcinoma cells; HepG2, Human hepatocellular carcinoma cells; LoVo, Human colon carcinoma cells; MDA-MB231, Human estrogen receptor (ER)-negative breast adenocarcinoma cells; Jurkat, Human T-lymphoid leukemia cells; K562, Human chronic myeloid leukemia cells

\section{INTRODUCTION}

Hemidesmus indicus R. Br. (Asclepiadaceae), also known as Indian sarsaparilla, is a common weed found all over India. Its root is widely used in ayurvedic traditional medicine, and it is an ingredient in its typical preparations alone or in combination with other plants (Ayurvedic Pharmacopoeia Committee, 1989).

Hemidesmus indicus roots have a wide variety of ethnomedicinal uses, the most important of which is probably the treatment of dysentery and diarrhea, but it is also used for other infections, skin disease, menorrhagia, postpartum recovery, stomach ulcer and gastric ailments, fever, headache, pain and inflammation, sore mouth, venereal disease including gonorrhea and syphilis, impotence, and as a blood purifier, cooling tonic and appetite stimulant, and to promote health and vitality

* Correspondence to: Filomena Conforti, Department of Pharmacy, Health and Nutrition Sciences, University of Calabria, Italy.

E-mail: filomena.conforti@unical.it and to neutralize snake bite and scorpion sting (Das et al., 2003; Austin, 2008). Under a pharmacological point of view, H.indicus has been studied for the first time in 1962, when the diuretic potential of its roots has been explored (Satoskar et al., 1962). Since then, four reviews and numerous other specific articles on the pharmacology of H.indicus have been published (Austin, 2008; Aneja et al., 2008; George et al., 2008; Das and Bisht, 2013), suggesting a wide range of beneficial effects, including chemopreventive and antitumour activity, hepatoprotection, free radical scavenging and antioxidant activity, cardioprotection, neuroprotection, antithrombotic and hypolipidemic effects, renal protection, antiulcer activity, and anti-infective and antiinflammatory activities through in vitro and in vivo research strategies (Das and Bisht, 2013). The pharmacological studies referred particularly to the decoction of the H.indicus roots, which is the preparation traditionally indicated in Pharmacopeia and Ayurvedic medicine. In this paper, we have compared the decoction with a hydroalcoholic extract, a traditional product used in western medicine. 
The major shortcoming in a large number of experimental and clinical studies is the absence of phytochemical standardization of the administrated preparations. Therefore, the aim of this research was to standardize the extracts, to define and quantify some specific markers and then, as required by International Agencies for the use approval of a drug as medicinal plant or food supplement, to highlight the correlation between chemical information and biological-therapeutic activities. For this reason, we have firstly performed the standardization of H.indicus root decoction and hydroalcoholic extract, and then, we have determined the in vitro antitumor activity against a panel of cancer cell lines in order to highlight their possible selective cytotoxic effects on cancer cells, comparing the obtained results with related literature data for decoction against HepG2 (Thabrew et al., 2005; Samarakoon et al., 2012) and contributing to extend the researches toward other cell lines not previously studied. Finally, in light of acquired evidences, regarding the chemical and functional characterization of each single preparation, suggestion about new therapeutic potential of $H$.indicus extracts was pointed out.

\section{MATERIALS AND METHODS}

Plant materials. The ayurvedic crude drug (roots) was collected in 2010 from Ram Bagh (Rajasthan, India), in particular, following the indications of Ayurvedic Pharmacopoeia of India (2004) during the balsamic period that is for H. indicus R. Br. roots in January (winter). This crude drug was authenticated by Dr. M. R Uniyal, Maharishi Ayurveda Product Ltd., Noida, India.

Chemicals. Gallic acid, hyperoside, cyanidin chloride, 2,2diphenyl-1-picrylhydrazyl (DPPH), 2,2'-azinobis(3-ethylbenzothiazoline-6-sulfonic acid)diammonium salt (ABTS),

Q2 Folin-Ciocalteau reagent, RPMI 1640 medium, fetal bovine serum (FBS), L-glutamine, penicillin/streptomycin, trypan blue, 3-(4,5-dimethylthiazol-2-yl)-2,5-diphenyltetrazolium bromide (MTT), lipase from porcine pancreas Type II, 4-nitrophenyl octanoate, orlistat, Griess reagent $(1 \%$ sulphonamide and $0.1 \% \quad N$-(1-naphtyl) ethylenedia-

Q3 minedihydrochloride in $2.5 \% \mathrm{H}_{3} \mathrm{PO}_{4}$ ), and $\mathrm{L}-\mathrm{NAME}$ were obtained from Sigma-Aldrich S.p.a. (Milano, Italy). MCF7 and A549 were purchased by Istituto Zooprofilattico Sperimentale della Lombardia e dell'Emilia-Romagna, Brescia, Italy; K562, CaCo2, MDA-MB-231, Jurkat,

Q4 HepG2, LoVo, and RAW 264.7 were from American Type Culture Collection. References substances (2-hydroxy-4-methoxybenzaldehyde, 3-hydroxy-4-methoxybenzaldehyde, and 2-hydroxy-4-methoxybenzoic acid) in HPLC analysis are from Sigma-Aldrich S.p.a. All other reagents, of analytical grade, were supplied by VWR International s.r.l. (Milan, Italy).

Extraction and preparation of formulations. The decoction was obtained by mixing $10 \mathrm{~g}$ of grinded roots with $300 \mathrm{~mL}$ of boiling water, allowing the volume of water to reach $75 \mathrm{~mL}$, according to the method previously described and agreed with Ayurvedic Pharmacopoeia
(Ferruzzi et al., 2013). The hydroalcoholic extract was prepared suspending $50 \mathrm{~g}$ of dried grinded roots in $450 \mathrm{~mL}$ of ethanolic solution $30 \%$ (v/v ethanol/water) and stirred for 21 days at $25^{\circ} \mathrm{C}$ (Préparations homéopathiques (1038), Pharmacopeè française, 11e edition). The two extracts were then filtered, lyophilized in an Edwards E-C Modulyo lyophilizer, and stored in the dark at $-20^{\circ} \mathrm{C}$. Both formulations were prepared 10 times to ensure the best statistical standardization. Resulting powders were then redissolved according to the corresponding assay conditions and checked for the amount of phytomarkers by HPLC before starting experiments. Vouchers of the lyophilized extracts were deposited in Department of Life Sciences and Biotechnology (SVeB) of the University of Ferrara and, respectively, coded as HEI01D and HEI01E.

Determination of total phenolics, anthocyanins, and flavonoids content and free radical scavenging activity. The determination of the total polyphenolic, flavonoidic, and procyanidin content in decoction and hydroalcoholic extract was performed using a Thermespectronic Helios- Q5 $\gamma$ spectrophotometer, according to previously described methods (Rossi et al., 2012). Total polyphenols were expressed as gallic acid, flavonoids as hyperoside, and procyanidins as cyanidin chloride.

Radical scavenging properties were performed in different assays, DPPH and ABTS tests, according to previously described methods (Rossi et al., 2012) to determine the $\mathrm{IC}_{50}$ value using ThermoSpectronic Helios- $\gamma$ spectrophotometer.

HPLC and nuclear magnetic resonance analyses. The decoction and the hydroalcoholic extract were subjected to HPLC analysis to quantify its main phytomarkers: 2-hydroxy-4-methoxybenzaldehyde, 3-hydroxy-4-methoxybenzaldehyde, and 2-hydroxy-4-methoxybenzoic acid. The reference compounds were used as external standards to set up and calculate appropriate calibration curves. The analyses were performed using a Jasco modular HPLC (model PU 2089, Tokyo, Japan) coupled to a diode array apparatus (MD 2010 Plus) according to the method described by Ferruzzi et al. (2013). To ensure the best standardization process of the two extracts, nuclear magnetic resonance fingerprinting has been acquired as described in our previous paper (Ferruzzi et al, 2013).

Cell line and cell culture. The human cancer cell lines MDA-MB-231, MCF-7, HepG2, CaCo2, and A549 were grown in Dulbecco's Modified Eagle's Medium (DMEM) supplemented with $10 \%$ FBS and 2 mM L-glutamine; LoVo in RPMI-1640 medium supplemented with $10 \%$ of FBS, $1 \%$ L-glutamine, and $1 \%$ antibiotic solution (penicillin/streptomycin); and K562 and Jurkat in RPMI-1640 medium supplemented with 10\% FBS, $50 \mathrm{U} / \mathrm{mL}$ penicillin, and $50 \mathrm{ug} / \mathrm{mL}$ streptomycin. Cells were maintained in a humidified atmosphere of $5 \%$ $\mathrm{CO}_{2}$ at $37^{\circ} \mathrm{C}$. After $4-5$ days, cells were removed from culture flask and centrifuged at $1500 \mathrm{rpm}$ for $10 \mathrm{~min}$. The medium was then removed and cells resuspended with fresh medium. Two types of tests were performed: Viability assay, for A549, CaCo2, HepG2, and LoVo 
cells, using a standard trypan blue cell counting technique and determination of cell proliferation using a

Q6 ZFZ Coulter Counter for all the other cell lines. The murine monocytic macrophage cell line RAW 264.7 was used to determine the inhibition of nitric oxide (NO) production. The cells were grown in Dulbecco's Modified Eagle's Medium in the same conditions as described earlier. Cell monolayers were subcultured onto 96 well culture plates $\left(1 \times 10^{5}\right.$ cells/well $)$ used for experiments $24 \mathrm{~h}$ later.

Evaluation of antiproliferative and cytotoxic effects. Cells growing in suspension (K562 and Jurkat) were seeded at an initial concentration of $3 \times 10^{-4}$ cells $/ \mathrm{mL}$ and cultured in the presence of increasing concentrations of compounds. Non-treated cells were considered as control. Cell growth was usually determined after 3, 4 , and 5 days of culture as cell number per mL, using a Zz Coulter Counter (Coulter Electronics, Hialeah, FL, USA). These time points were selected because between days 3 and 5, untreated controls K562 and Jurkat cells are on the log phase of cell growth (Bianchi et al., 2000). Adherent cells (MDA-231 and MCF-7) were cultured at an initial concentration of $1.5 \times 10^{-4}$ cells $/ \mathrm{mL}$, treated with increasing concentrations of compounds

Q7 and after $72 \mathrm{~h}$ washed with sterile phosphate-buffered saline $1 \mathrm{X}$ and trypsinized. Cell growth was monitored as described for K562 and Jurkat cell lines.

For the others cell lines (HepG2, LoVo, CaCo2, and A549) the MTT assay, reported previously (Marrelli et al., 2013), was used to estimate cell number indirectly. Cell monolayers were subcultured onto 96 well culture plates $\left(2 \times 10^{4}\right.$ cells/well $)$ and treated with serial concentrations of the samples. After $24 \mathrm{~h}$ of incubation, $100 \mu \mathrm{L}$ of medium were removed from each well. Subsequently, $100 \mu \mathrm{L}$ of $0.5 \% \mathrm{w} / \mathrm{v}$ MTT, dissolved in phosphatebuffered saline, was added to each well and allowed to incubate further for $4 \mathrm{~h}$. After $4 \mathrm{~h}$ of incubation, $100 \mu \mathrm{L}$ of dimethyl sulfoxide was added to each well to dissolve the formazan crystals. Absorbance values at $550 \mathrm{~nm}$ were measured with a microplate reader (GDV DV 990 B/V, Roma, Italy). Cytotoxicity was expressed as LD50, which is the concentration needed to reduce the absorbance of treated cells by $50 \%$ with reference to the control (untreated cells). Doxorubicin was taken as positive control.

\footnotetext{
Inhibition of nitric oxide production in lipopolysaccharide-stimulated RAW 264.7 cells. The murine monocytic macrophage cells RAW 264.7 were cultured with different concentrations of extracts for $24 \mathrm{~h}$, after addition of LPSs (final concentration of $1 \mu \mathrm{g} / \mathrm{mL}$ ) for antiinflammatory tests. The presence of nitrite, a stable oxidized product of NO, was determined in cell culture media $24 \mathrm{~h}$ later by the Griess reagent (1\% sulfanamide and $0.1 \% N$-(1-naphtyl)ethylenediaminedihydrochloride in $2.5 \% \mathrm{H}_{3} \mathrm{PO}_{4}$ ) as previously described (Conforti et al., 2012). About $100 \mu \mathrm{L}$ of cell culture supernatant was combined with $100 \mu \mathrm{L}$ of Griess reagent in a 96 well plate followed by spectrophotometric measurement at $550 \mathrm{~nm}$ using a microplate reader (GDV DV 990 B/V, Roma, Italy). Cytotoxicity was assessed using the MTT assay.
}

SOS-chromotest. Genotoxicity and antigenotoxicity assays were performed in accordance with Quillardet and Hofnung (1985). Exponential-phase culture of Escherichia coli PQ37 was obtained as follows: an aliquot of bacterial culture was inoculated to $5 \mathrm{~mL}$ of fresh LA medium (lyserom $20 \mu \mathrm{g} / \mathrm{mL}$ ampicillin) and left to grow overnight and shaken constantly at $37^{\circ}$ C. Of the precedent culture, $1 \mathrm{~mL}$ was then added to $5 \mathrm{~mL}$ of fresh LA medium and was grown at $37^{\circ} \mathrm{C}$ for $3.5 \mathrm{~h}$. At this point, the bacterial concentration was $2 \times 10^{8} \mathrm{UFC} / \mathrm{mL}$; the solution had an optical density closed to $\lambda=0.6$.

This solution was diluted 1:10 with fresh LB medium, and $0.6 \mathrm{ml}$ was distributed into test tubes containing $20 \mu \mathrm{L}$ of genotoxic agent, 4 -nitroquinoline $N$-oxide, and $20 \mu \mathrm{L}$ of a solution of tested material (H.indicus decoction and hydroalcoholic extract, and pure molecules) in several concentrations. Every sample was dissolved in dimethyl sulfoxide and tested in triplicate. After $2 \mathrm{~h}$ of incubation at $37^{\circ} \mathrm{C}$, the evaluation of the genotoxic/antigenotoxic activity ( $\beta$-galactosidase) and the cell viability (alkaline phosphatase) started.

To perform antigenotoxic assay (evaluation of the $\beta$-galactosidase expression), the method was the following: $0.3 \mathrm{~mL}$ of the last obtained bacterial solution was added to $2.7 \mathrm{~mL}$ of $\mathrm{B}$ buffer. After a period of incubation of $10 \mathrm{~min}$ at $37^{\circ} \mathrm{C}, 0.6 \mathrm{~mL}$ of a $0.4 \%$ solution of 2nitrophenyl $\beta$-D-galactopyranoside was added. After another $60 \mathrm{~min}$ of incubation, the addition of $2 \mathrm{~mL}$ of $\mathrm{Na}_{2} \mathrm{CO}_{3} 1 \mathrm{M}$ solution stopped the reaction. The color of the mixture was read with a ThermoSpectronic Helios- $\gamma$ spectrophotometer at wavelength of $420 \mathrm{~nm}$.

For viability assay (evaluation of the alkaline phosphatase expression), the procedure stated that at the same time of the $\beta$-galactosidase assay, $0.3 \mathrm{ml}$ of bacterial solution was added to $7 \mathrm{~mL}$ of $\mathrm{P}$ buffer. In this case, after a period of incubation of $10 \mathrm{~min}$ at $37^{\circ} \mathrm{C}, 0.6 \mathrm{~mL}$ of a $0.4 \%$ solution of 4-nitrophenyl phosphate disodium salt hexahydrate was added. After another $60 \mathrm{~min}$ of incubation, the addition of $1 \mathrm{~mL}$ of $\mathrm{HCl} 2.5 \mathrm{M}$ stopped the reaction and caused the color disappearance. Five minutes later, the addition of $1 \mathrm{~mL}$ of tris(hydroxymethyl) aminomethane $2 \mathrm{M}$ changed the $\mathrm{pH}$ restoring the color. The mixture was read with a ThermoSpectronic Helios- $\gamma$ spectrophotometer at wavelength of $420 \mathrm{~nm}$.

Statistical analysis. All experiments were carried out in triplicate. Data were expressed as means \pm standard error of mean. The concentration yielding $50 \%$ inhibition $\left(\mathrm{IC}_{50}\right)$ was calculated by nonlinear regression with the use of Prism Graphpad version 4.0 for Windows (GraphPad Software, San Diego, CA, USA). Statistical significance was assessed with one-way analysis of variance using SigmaStat software (Jantel scientific software, San Rafael, CA, USA). Significant differences among means were analyzed using Tukey's multiple comparisons test. Differences at $p<0.05$ were considered significant.

\section{RESULTS AND DISCUSSION}

The yield of decoction was of $25.6 \%$, analogously to what was recently reported (Guerrini et al., 2014), while 
Table 1. Yields, total polyphenols, procyanidins, and flavonoids of Hemidesmus indicus extracts

\begin{tabular}{lcc}
\hline & Decoction & Hydroalcoholic extract \\
\hline Yield (g/100 g of dried drug) & $25.6 \pm 0.4$ & $17.1 \pm 0.1$ \\
Total polyphenols $^{1}$ & $11.60 \pm 0.60$ & $12.34 \pm 0.48$ \\
Total procyanidins $^{2}$ & $0.62 \pm 0.04$ & $0.37 \pm 0.02$ \\
Total flavonoids $^{3}$ & $2.19 \pm 0.20$ & $0.89 \pm 0.05$ \\
\hline
\end{tabular}

${ }^{1}$ Per $100 \mathrm{~g}$ of lyophilized decoction, expressed as gallic acid.

${ }^{2}$ Per $100 \mathrm{~g}$ of lyophilized decoction, expressed as cyanidin chloride.

${ }^{3}$ Per $100 \mathrm{~g}$ of lyophilized decoction, expressed as hyperoside.

T1 for hydroalcoholic extract, it was $17.06 \%$ (Table 1), but for this latter, no data were shown in related literature for a comparison. Both extracts were chemically characterized to highlight their differences and performed their standardization and evidence of possible correlations and exploitations with biological activities. As previously suggested in literature (Ferruzzi et al., 2013; Das and Bisht, 2013), we have determined the amount

F1 T2 of main H.indicus phytomarkers (Table 2 and Fig. 1), 2-hydroxy-4-methoxybenzaldehyde, 3-hydroxy-4-meth. oxybenzaldehyde, and 2-hydroxy-4-methoxybenzoic acid, the content of all three compounds was higher in hydroalcoholic solution with 2-hydroxy-4-methoxybenzaldehyde as the most abundant $(214.5 \mu \mathrm{g} / \mathrm{mL}$ and $0.879 \mathrm{~g} / 100 \mathrm{~g}$ ). If compared with total polyphenols data (Table 1), the amount due to the phytomarkers represented about $10 \%$ of the whole content of polyphenols, suggesting that other possible molecules, such as hemidesmins (Das et al., 1992) and derivatives of vanillin isomers (Zhao et al., 2014) could also be investigated. From 6 to $10 \mathrm{ppm}$, the nuclear magnetic resonance fingerprinting of hydroalcoholic extract highlighted the typical chemical shifts of 2-hydroxy-4methoxybenzaldehyde, the most abundant phytomarker

F2 among those quantified by HPLC (Fig. 2).

The two $H$.indicus preparations were first tested for their cytotoxic effects using a panel of cancer cell lines commonly used for these assays, such as colorectal adenocarcinoma $\mathrm{CaCo}$, lung carcinoma A549, hepatocellular carcinoma HepG2, and colon carcinoma LoVo cells. Cytotoxicity was determined after $24 \mathrm{~h}$ of treatment. The results on the cytotoxic effects of $H$.indicus T3 Q10 preparations are depicted in Table 3. Both preparations exhibited weak cytotoxicity on A549, CaCo2, and LoVo cell lines to the highest tested concentration of $100 \mu \mathrm{g} / \mathrm{mL}\left(\mathrm{IC}_{50}>100 \mu \mathrm{g} / \mathrm{mL}\right)$. Cytotoxicity of H.indicus preparations was, on the contrary, found against the HepG2 cell line. These results are in line with previous studies showing that H.indicus decoction is cytotoxic on HepG2 cells (Thabrew et al., 2005). In the present research, we showed that hydroalcoholic extracts can also be responsible for cytotoxic activity. In fact, the
H. indicus hydroalcoholic preparations displayed a cytotoxic activity $\left(\mathrm{IC}_{50}\right.$ values of $\left.34.50 \mu \mathrm{g} / \mathrm{mL}\right)$ similar to that of the decoction $\left(\mathrm{IC}_{50}\right.$ values of $\left.33.52 \mu \mathrm{g} / \mathrm{mL}\right)$. As for the decoction, the hydroalcoholic extract was not cytotoxic against the $\mathrm{A} 549$ and $\mathrm{CaCo} 2$ cell lines. On the contrary, cytotoxicity was found when treatment was performed on LoVo cells.

After these preliminary assays, we determined the in vitro antiproliferative activity selecting the breast cancer MCF-7 cells in comparison with the more aggressive MDA-MB-231 cell line. In addition to these experimental model systems for solid tumors, we determined the antiproliferative activity on the erythroleukemia K562 and T-lymphoid Jurkat cell lines. In these assays, the cells were cultured in the absence or presence of the tested agents and the cell number per $\mathrm{mL}$ determine after 3 and 4 days, when the untreated cells are in the log phase of in vitro cell growth. The results of these experiments are shown in Table 4. We found that MDA-MB-231 isT4 resistant to all the treatments (inhibition of cell proliferation is obtained only at concentrations greater than $500 \mu \mathrm{g} / \mathrm{mL}$ ). On the contrary, the hydroalcoholic preparation displayed activity of MCF-7 cells at about $200 \mu \mathrm{g} / \mathrm{mL}$. K562 and Jurkat cells were differently sensitive to the treatments, because the decoction was only active on Jurkat cells, while the hydroalcoholic preparation was active on both $\mathrm{K} 562$ ( $\mathrm{IC}_{50}$ values of $177.11 \mu \mathrm{g} / \mathrm{mL}$ ) and Jurkat ( $\mathrm{IC}_{50}$ values of $\left.63.79 \mu \mathrm{g} / \mathrm{mL}\right)$ cells.

These data are of interest when compared with a previous study (Thabrew et al., 2005) showing that the decoction prepared with Nigella sativa seeds, H.indicus (roots), and Smilax glabra (rhizome), used by traditional medical practitioners in Sri Lanka to treat cancer, has a dose-dependent inhibition activity with the maximum effect at concentrations higher than $40 \mathrm{mg} / \mathrm{mL}$ (dose causing $50 \%$ inhibition, $\mathrm{ED}_{50}=17 \mathrm{mg} / \mathrm{mL}$ ). All three individual plant extracts demonstrated inhibitory activity with interesting $H$.indicus values for $\mathrm{ED}_{50}(32 \mathrm{mg} / \mathrm{mL})$. Our study showed instead the strongly different results for the H.indicus decoction evidencing $\mathrm{IC}_{50}$ values almost 1000 -fold lower $(33.52 \mu \mathrm{g} / \mathrm{mL})$ than those reported by related paper $(32 \mathrm{mg} / \mathrm{mL})$, at least in some of the tumor cell lines used.

Moreover, the study of Samarakoon et al. (2012) demonstrated that the decoction of $N$. sativa seeds, $H$.indicus roots, and S.glabra rhizomes can induce apoptosis in human hepatocellular carcinoma HepG2 cell, in a dose and time-dependent manner through the activation of caspase-3 and caspase-9, and upregulation of pro-apoptotic Bax and downregulation of anti-apoptotic Bcl-2 genes, which are involved in intrinsic or mitochondrial pathway of apoptosis.

No previous studies were conducted against human colon carcinoma cell line (LoVo) for which the hydroalcoholic extract showed the best antiproliferative activity.

Table 2. HPLC quantification of chemical compounds in Hemidesmus indicus extracts

\begin{tabular}{|c|c|c|c|c|}
\hline & \multicolumn{2}{|c|}{ Decoction } & \multicolumn{2}{|c|}{ Hydroalcoholic extract } \\
\hline & $(\mu \mathrm{g} / \mathrm{mL})$ & $(\mathrm{g} / 100 \mathrm{~g})$ & $(\mu \mathrm{g} / \mathrm{mL})$ & $(\mathrm{g} / 100 \mathrm{~g})$ \\
\hline 2-Hydroxy-4-methoxy-benzaldehyde & $1.72 \pm 0.09$ & $0.050 \pm 0.003$ & $214.54 \pm 5.17$ & $0.879 \pm 0.021$ \\
\hline 3-Hydroxy-4-methoxy-benzaldehyde & $26.85 \pm 0.92$ & $0.788 \pm 0.027$ & $57.10 \pm 1.39$ & $0.234 \pm 0.006$ \\
\hline 2-Hydroxy-4-methoxy-benzoic acid & $23.54 \pm 0.23$ & $0.691 \pm 0.007$ & $32.51 \pm 1.23$ & $0.133 \pm 0.005$ \\
\hline
\end{tabular}




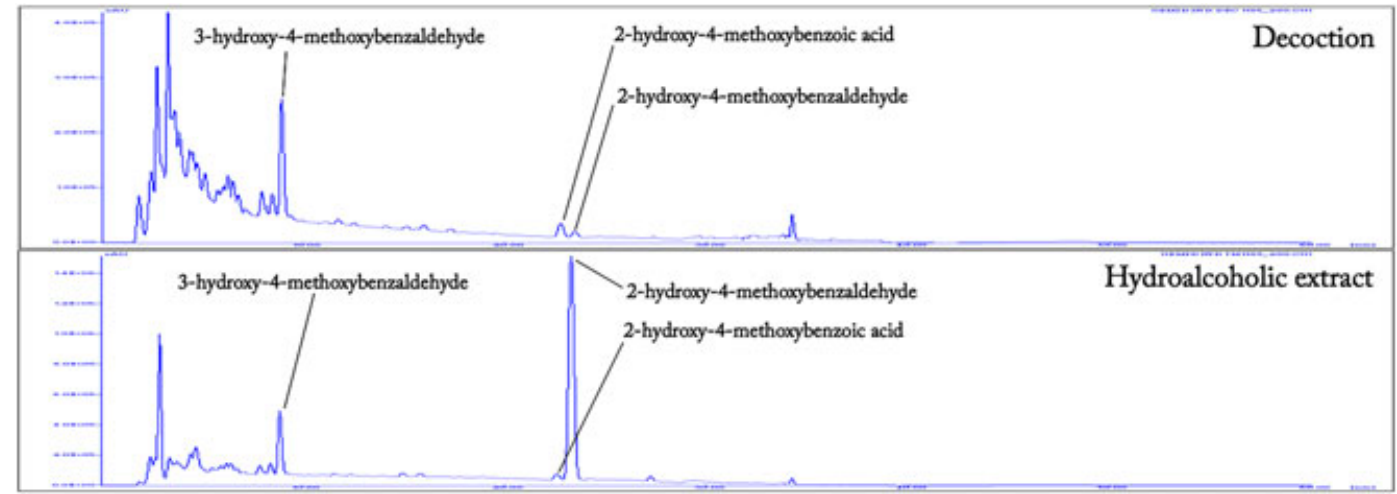

Figure 1. HPLC chromatograms of the two extracts.

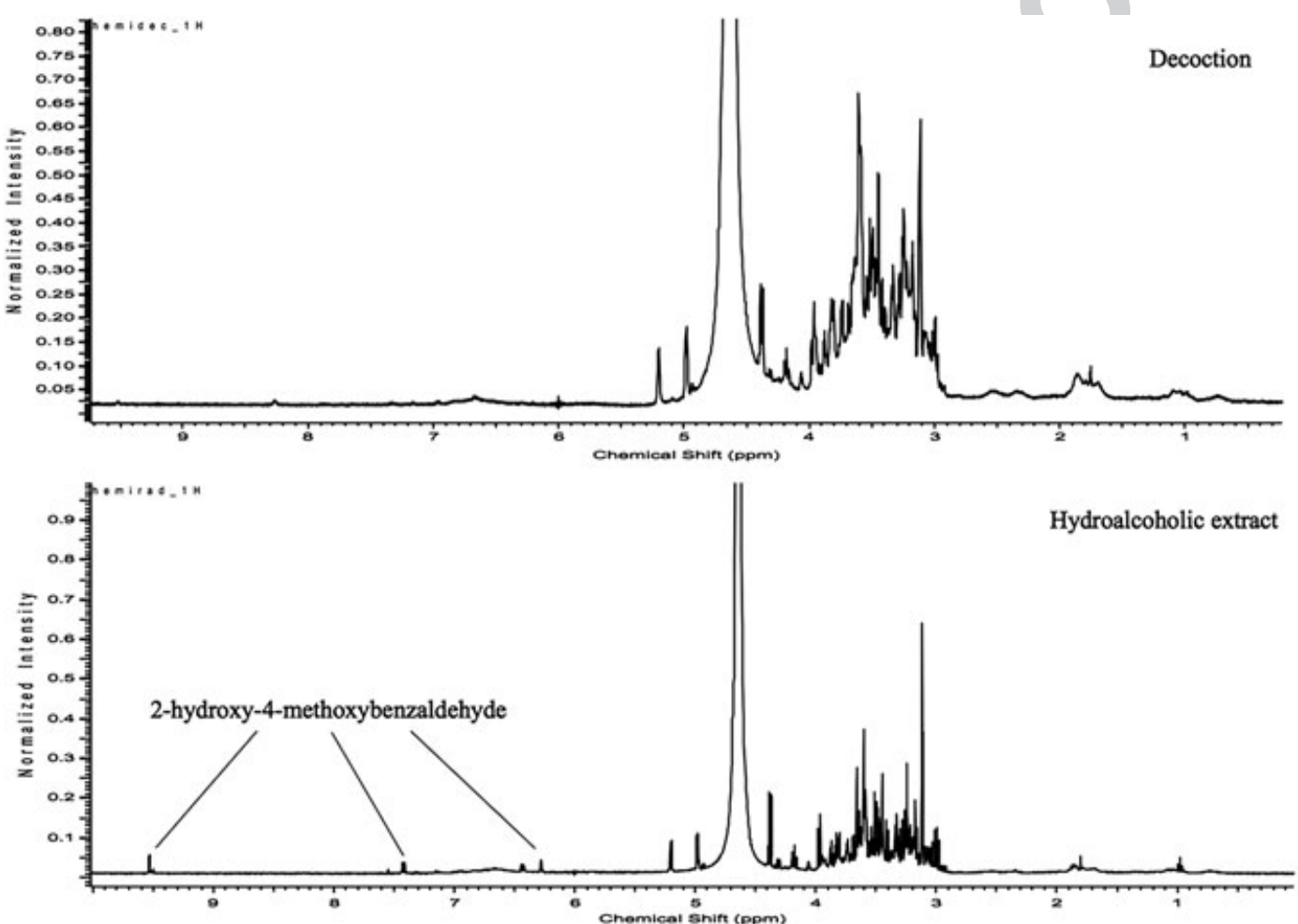

Figure 2. Proton nuclear magnetic resonance fingerprinting of the two extracts.

Table 3. Cytotoxic activities of preparations and pure molecules from Hemidesmus indicus

\begin{tabular}{|c|c|c|c|c|c|c|}
\hline \multicolumn{7}{|c|}{$\mathrm{IC}_{50}(\mu \mathrm{g} / \mathrm{mL})$} \\
\hline Cell line & $\begin{array}{l}\text { Decoction } \\
(\mu \mathrm{g} / \mathrm{mL})\end{array}$ & $\begin{array}{l}\text { Hydroalcoholic extract } \\
\qquad(\mu \mathrm{g} / \mathrm{mL})\end{array}$ & $\begin{array}{c}\text { 2-OH-4-OMeald } \\
(\mu \mathrm{M})\end{array}$ & $\begin{array}{c}\text { 3-OH-4-OMeald } \\
(\mu \mathrm{M})\end{array}$ & $\begin{array}{c}\text { 2-OH-4-OMeac } \\
(\mu \mathrm{M})\end{array}$ & $\begin{array}{l}\text { Doxorubicin } \\
(\mu \mathrm{M})\end{array}$ \\
\hline A549 & $>500$ & $>500$ & $>200$ & $>200$ & $>200$ & - \\
\hline $\mathrm{CaCo} 2$ & $>500$ & $>500$ & $>200$ & $>200$ & $>200$ & - \\
\hline HepG2 & $33.52( \pm 0.13)$ & $34.50( \pm 0.14)$ & $>200$ & $>200$ & $>200$ & $0.39( \pm 0.02)$ \\
\hline LoVo & $>500$ & $29.84( \pm 0.24)$ & $>200$ & $>200$ & $>200$ & $0.58( \pm 0.04)$ \\
\hline
\end{tabular}

In addition, with respect to isolated compounds, while 3-hydroxy-4-methoxy-benzaldehyde and 2-hydroxy-4methoxy-benzoic acid were not or barely active on all the cell lines employed $\left(\mathrm{IC}_{50}\right.$ values $\left.>200 \mu \mathrm{g} / \mathrm{mL}\right)$, 2-hydroxy-4-methoxy-benzaldehyde inhibited the in vitro proliferation of K562 and Jurkat cells, displaying low activity on MCF-7 and MDA-MB-231 cells.
When the effects of the H.indicus decoction and hydroalcoholic preparation are compared with those of the plant-derived products, we can conclude that the obtained results reflect the typical efficacy expression of plant-derived products where bioactivities do not complete because of a single compound but often to a synergic interaction among different molecules present 
Table 4. Antiproliferative effects of preparations and pure molecules from Hemidesmus indicus

\begin{tabular}{|c|c|c|c|c|c|}
\hline & & & $\mathrm{IC}_{50}(\mu \mathrm{g} / \mathrm{mL})$ & & \\
\hline Cell line & Decoction $(\mu \mathrm{g} / \mathrm{mL})$ & Hydroalcoholic extract ( $\mu \mathrm{g} / \mathrm{mL})$ & 2-OH-4-OMeald $(\mu \mathrm{M})$ & 3-OH-4-OMeald ( $\mu \mathrm{M})$ & 2-OH-4-OMeac. $(\mu \mathrm{M})$ \\
\hline MCF-7 & $829.32( \pm 74.14)$ & $209.73( \pm 18.75)$ & $498.67( \pm 44.58)$ & $>1000$ & $>1000$ \\
\hline MDA-MB-231 & $732.40( \pm 65.48)$ & $521.65( \pm 46.63)$ & $448.32( \pm 40.08)$ & $>1000$ & $>1000$ \\
\hline K562 & $585.95( \pm 99.0)$ & $177.11( \pm 15.83)$ & $79.52( \pm 18.27)$ & $361.57( \pm 10.81)$ & $658.41( \pm 10.79)$ \\
\hline Jurkat & $349.66( \pm 49.38)$ & $63.79( \pm 7.97)$ & $86.46( \pm 3.66)$ & $329.96( \pm 17.20)$ & $790.37( \pm 70.66)$ \\
\hline
\end{tabular}

Table 5. Determination of antioxidant activity with ABTS and DPPH tests

\begin{tabular}{lcccccc}
\hline & \multicolumn{5}{c}{$I_{50}(\mu \mathrm{g} / \mathrm{mL})$} \\
\hline & Decoction & Hydroalcoholic extract & 2-Hydroxy-4-OMeald & 3-Hydroxy-4-OMeald & 2-Hydroxy-4-OMeac & Trolox \\
\hline ABTS test & $29.4 \pm 1.4$ & $9.44 \pm 0.47$ & $8.17 \pm 0.41$ & $1.03 \pm 0.06$ & $23.6 \pm 0.3$ & $2.40 \pm 0.12$ \\
DPPH test & $82.3 \pm 4.1$ & $69.4 \pm 3.5$ & $>1000$ & $>1000$ & $>1000$ & $4.95 \pm 0.26$ \\
\hline
\end{tabular}

ABTS, 2,2'-azinobis(3-ethylbenzothiazoline-6-sulfonic acid)diammonium salt; DPPH, 2,2-diphenyl-1-picrylhydrazyl.

in different amounts. Epidemiological studies have established that many tumors occur in association with chronic infectious diseases, and it is also known that persistent inflammation in the absence of infections increases the risk and accelerates the development of cancer (Balkwill et al., 2005). NO is known to play an important role in maintenance of tissue homeostasis; it is produced by NO synthase, whose inducible isoform (iNOS) is known to be implicated in several pathological conditions and inflammation. NO produced by iNOS kills infectious pathogens, but overproduction of NO results in damage to tissues and, eventually, destruction of tissue homeostasis (Kröncke et al., 1998). Thus, iNOS expression and NO production might be a good target for research into disturbed inflammatory conditions. Macrophages can release inflammatory mediators, such as prostaglandins, cytokines, and NO in response to LPS stimulation, validating use of LPS-treated macrophages as a model of inflammation. Here, the hydroalcoholic extract caused inhibition of NO production in the murine monocytic macrophage cell line RAW 264.7, with inhibition of $32 \%$.

For what concerns antioxidant capacity, the most interesting radical scavenging activity, in particular with ABTS test, has been shown by hydroalcoholic extract $\left(\mathrm{IC}_{50}=9.44 \mu \mathrm{g} / \mathrm{mL}\right)$ with respect to Trolox $\left(\mathrm{IC}_{50}=2.40 \mu \mathrm{g} / \mathrm{mL}\right)$ taken as the positive control T5 (Table 5). Literature reported a good correlation between total phenolic content and antioxidant activity (Paixão et al., 2007). The hydroalcoholic extract evidenced only a slightly higher amount of total polyphenols than that of decoction, but the relevant activities of 2-hydroxy-4-methoxy-benzaldehyde $\left(\mathrm{IC}_{50}=8.17 \mu \mathrm{g} / \mathrm{mL}\right)$ and 3-hydroxy-4-methoxy-benzaldehyde $\left(\mathrm{IC}_{50}=1.03 \mu \mathrm{g} / \mathrm{mL}\right)$, presenting in higher amount in alcoholic extract than in decoction, can explain the better antioxidant capacity of the first phytocomplex. On the other hand, the good antioxidant activity of 2-hydroxy-4-methoxybenzaldehyde has been yet reported in literature (Wang et al., 2010). However, the DPPH test did not support this evidence for the aldehyde compounds; further investigations are required for better discuss these results.

Finally, in order to check possible genotoxic/ genoprotective properties of $H$.indicus traditional preparations and single compounds, the SOS-chromotest was performed. The assay gave negative response, toward cytotoxicity and DNA damage, in presence of decoction, hydroalcoholic extract, and their phytomarkers, except for the 2-hydroxy-4-methoxybenzoic acid that showed cytotoxicity at concentrations equal and higher than $125 \mu \mathrm{g} / \mathrm{mL}$. Therefore, it was impossible to assess the genotoxic potential after this value, but it exhibits a $30 \%$ inhibition at $75 \mu \mathrm{g} / \mathrm{mL}$. The SOS induction was caused by a $2.5 \mu \mathrm{g} / \mathrm{mL}$ solution of 4 -nitroquinoline $N$-oxide, and the inhibition of the system was registered in the tests conducted with hydroalcoholic extract $(39.56 \%$

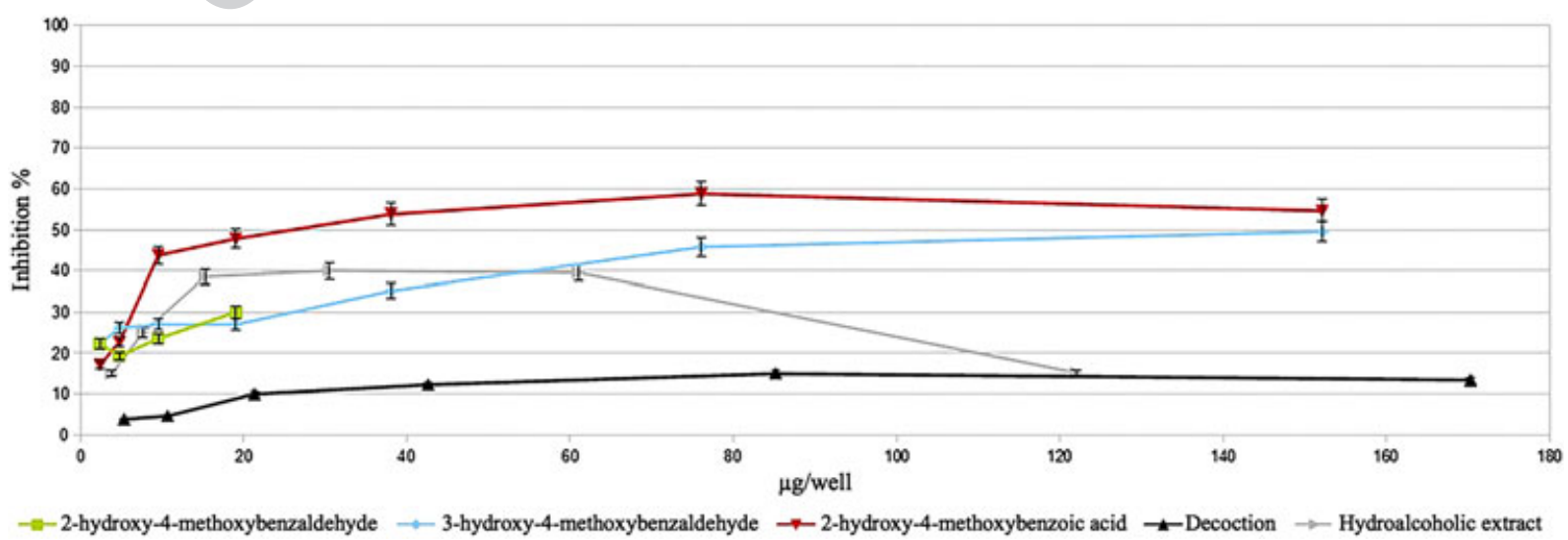

Figure 3. Genotoxic action of preparations and pure molecules. 
of inhibition at $300 \mu \mathrm{g} / \mathrm{mL})$, 3-hydroxy-4-methoxybenzaldehyde $(45.79 \%$ of inhibition at $375 \mu \mathrm{g} / \mathrm{mL})$, and 2 hydroxy-4-methoxybenzaldehyde that exhibit the highest genoprotective potential $(58.79 \%$ of inhibition at

F3 $375 \mu \mathrm{g} / \mathrm{mL}$ ) (Fig. 3). Decoction and pure compounds followed a dose-response correlation, while the last two concentrations of hydroalcoholic extract did not respect the same trend, this fact could be due to the dark color of phytocomplex solution. The activity of the this latter could be explained in light of the observations that 2-hydroxy-4-methoxybenzaldehyde was the most active compound present 200 times more concentrated in this phytocomplex than decoction. However, we cannot exclude the possibility that the inhibitory effect of this preparation could be ascribed to possible agonistic effect of other compounds.

\section{CONCLUSIONS}

The results of the study provide further supporting data for the reported anticancer potential of the decoction of $H$.indicus that will help to determine its selective cytotoxic effects on cancer cells. In particular, decoction showed promising effect on HepG2 cells, while the hydroalcoholic extract was active against HepG2, LoVo, MCF-7, K562, and Jurkat cell lines. An interesting antioxidant activity, particularly for hydroalcoholic extract in ABTS test, may be correlated to the higher amount of 2-hydroxy-4-methoxybenzaldehyde in this preparation. A relevant aspect of our research was also the standardization of the two preparations, in order to give more solid foundation to develop further investigations. Overall findings provide confirmatory evidence to demonstrate the activity of the decoction, traditionally used in Ayurveda, and its comparison with hydroalcoholic extract for new perspectives of uses as food supplement.

\section{Acknowledgements}

This research was supported by a PRIN grant (Progetti di Ricerca di Interesse Nazionale, MIUR of Italy) coded 2009LR9YLF_001.

\section{Conflict of Interest}

The authors are no conflict of interest

\section{REFERENCES}

Aneja V, Suthar A, Verma S, Kalkunte S. 2008. Phyto-pharmacology of Hemidesmus indicus. Pharmacogn Rev 2: 143-150.

Austin A. 2008. A review on Indian Sarsaparilla, Hemidesmus indicus (L.) R. Br. J Biol Sci 8: 1-12.

Ayurvedic Pharmacopoeia Committee 1989. Hemidesmus indicus. Government of India, Ministry of Health and Family Welfare, Department of Ayurveda, Yoga and Naturopathy, Unani, Siddha and Homoeopathy (AYUSH). The Ayurvedic Pharmacopoeia of India, New Delhi, 107.

Balkwill F, Charles KA, Mantovani A. 2005. Smoldering and polarized inflammation in the initiation and promotion of malignant disease. Cancer Cell 7: 211-217.

Q11Bendicho S, Trigueros MG, Hernàndez T, Martin O. 2001. Valida tion and comparison of analytical methods based on the release of $\mathrm{p}$-nitrophenol to determine lipase activity in milk. $d$ Dairy Sci 84: 1590-1596.

Bianchi N, Ongaro F, Chiarabelli C, et al. 2000. Induction of erythroid differentiation of human K562 cells by cisplatin analogs. Biochem Pharmacol 31-40.

Conforti F, Menichini F, Formisano C, et al. 2012. Anthemis wiedemanniana essential oil prevents LPS-induced production of NO in RAW 264.7 macrophages and exerts antiproliferative and antibacterial activity. Nat Prod Res 26: 1594-1601.

Das PC, Joshi PC, Mandal S, Das A, Chatterjee A. 1992. New coumarinolignoids from Hemidesmus indicus $\mathrm{R}$. Br. Indian $J$ Chem 31: 342-345.

Das S, Dash SK, Padhy SN. 2003. Ethnomedicinal information from the tribals of Orissa state-review. J Hum Ecol 14: 165-227.

Das S, Bisht SS. 2013. The bioactive and therapeutic potential of Hemidesmus indicus $\mathrm{R}$. Br. (Indian Sarsaparilla) root. Phytother Res 27: 791-801.

Ferruzzi L, Turrini E, Burattini S, et al. 2013. Hemidesmus indicus induces apoptosis as well as differentiation in a human promyelocytic leukemic cell line. J Ethnopharmacol 147: 84-91.

George S, Tushar KV, Unnikrishnan KP, Hasim KM, Balachandran I. 2008. Hemidesmus indicus (L.) R. Br. A review. J Plant Sci 3: 146-156.

Guerrini A, Mancini I, Maietti S, et al. 2014. Expression of proinflammatory interleukin-8 is reduced by ayurvedic decoctions. Phytother Res 28: 1173-1181.
Kröncke KD, Fehsel K, Kolb-bachofen V. 1998. Inducible nitric oxide synthase in human diseases. Clin Exp Immunol 113: 147-156.

Marrelli M, Conforti F, Rigano D, et al. 2013. Cytotoxic properties of Marrubium globosum ssp. libanoticum and its bioactive components. Nat Prod Commun 8: 567-569.

Préparations homéopathiques. 1038. Pharmacopeè française, 11 e édition.

Paixão N, Perestrelo R, Marques JC, Câmara JS. 2007. Relationship between antioxidant capacity and total phenolic content of red, rosé and white wines. Food Chem 105: 204-214.

Quillardet P, Hofnung M. 1985. The SOS chromotest, a colorimetric bacterial assay for genotoxins: procedures. Mutat Res 147 $65-78$.

Rossi D, Guerrini A, Bruni R, et al. 2012. Trans-resveratrol in nutraceuticals: issues in retail quality and effectiveness. Molecules 17: 12393-12405.

Samarakoon SR, Thabrew I, Galhena PB, Tennekoon KH. 2012. Modulation of apoptosis in human hepatocellular carcinoma (HepG2 cells) by a standardized herbal decoction of Nigella sativa seeds, Hemidesmus indicus roots and Smilax glabra rhizomes with anti-hepatocarcinogenic effects. BMC Complement Altern Med 12: 25.

Satoskar RS, Shah LG, Bhatt K, Sheth UK. 1962. Preliminary study of pharmacologic properties of Anantmul (Hemidesmus indicus). Indian J Physiol Pharmacol 6: 68-76.

Thabrew MI, Mitry RR, Morsy MA, Hughes RD. 2005. Cytotoxic effects of a decoction of Nigella sativa, Hemidesmus indicus and Smilax glabra on human hepatoma HepG2 cells. Life Sci 77: 1319-1330.

Wang J, Liu H, Zhao J, et al. 2010. Antimicrobial and antioxidant activities of the root bark essential oil of Periploca sepium and its main component 2-hydroxy-4-methoxybenzaldehyde. Molecules 15: 5807-5817.

Zhao Z, Matsunami K, Otsuka H, Negi N, Kumar A, Negi DS. 2014. A condensed phenylpropanoid glucoside and pregnane saponins from the roots of Hemidesmus indicus. J Nat Med 67: $137-142$ 


\section{Author Query Form}

\section{Journal: Phytotherapy Research}

\section{Article: ptr_5322}

Dear Author,

During the copyediting of your paper, the following queries arose. Please respond to these by annotating your proofs with the necessary changes/additions.

- If you intend to annotate your proof electronically, please refer to the E-annotation guidelines.

- If you intend to annotate your proof by means of hard-copy mark-up, please use the standard proofing marks. If manually writing corrections on your proof and returning it by fax, do not write too close to the edge of the paper. Please remember that illegible mark-ups may delay publication.

Whether you opt for hard-copy or electronic annotation of your proofs, we recommend that you provide additional clarification of answers to queries by entering your answers on the query sheet, in addition to the text mark-up.

\begin{tabular}{|c|c|c|}
\hline Query No. & Query & Remark \\
\hline Q1 & $\begin{array}{l}\text { AUTHOR: Please confirm that given names (red) and surnames/family names (green) } \\
\text { have been identified correctly. }\end{array}$ & \\
\hline Q2 & AUTHOR: Please define RPMI on first mention. & \\
\hline Q3 & AUTHOR: Please define L-NAME on first mention. & \\
\hline Q4 & $\begin{array}{l}\text { AUTHOR: Please give address information for American Type Culture Collection: } \\
\text { town, state (if applicable), and country. }\end{array}$ & \\
\hline Q5 & $\begin{array}{l}\text { AUTHOR: Please give manufacturer information forThermoSpectronic Helios- } \gamma \\
\text { spectrophotometer: company name, town, state (if USA), and country. }\end{array}$ & \\
\hline Q6 & $\begin{array}{l}\text { AUTHOR: Do you mean to say "Z2 Coulter Counter"? Please provide its manufacturer } \\
\text { information: company name, town, state (if USA), and country if this is not the same as } \\
\text { "Z2 Coulter Counter" found in the next paragraph. }\end{array}$ & \\
\hline Q7 & $\begin{array}{l}\text { AUTHOR: 'phosphate-buffered saline'. Is this the correct definition for PBS? Please } \\
\text { change if this is incorrect. }\end{array}$ & \\
\hline Q8 & AUTHOR: Please define SOS on first mention. & \\
\hline Q9 & AUTHOR: Please define LA medium and LB medium on first mention. & \\
\hline Q10 & AUTHOR: Tables have been renumbered according to citation order. Please check. & \\
\hline Q11 & $\begin{array}{l}\text { AUTHOR: Reference "Bendicho et al. (2001)" is not cited in the text. Please indicate } \\
\text { where it should be cited; or delete from the reference list. }\end{array}$ & \\
\hline Q12 & AUTHOR: Please provide the volume number for reference Bianchi et al. [2000]. & \\
\hline Q13 & AUTHOR: Please check and provide complete details for this reference if necessary. & \\
\hline Q14 & $\begin{array}{l}\text { AUTHOR: Revised figures } 1,2 \text { and } 3 \text { still contains small and poor quality of text. Please } \\
\text { check and resupply if necessary. }\end{array}$ & \\
\hline
\end{tabular}


Required software to e-Annotate PDFs: Adobe Acrobat Professional or Adobe Reader (version 7.0 or above). (Note that this document uses screenshots from Adobe Reader $\mathrm{X}$ )

The latest version of Acrobat Reader can be downloaded for free at: http://get.adobe.com/uk/reader/

Once you have Acrobat Reader open on your computer, click on the Comment tab at the right of the toolbar:

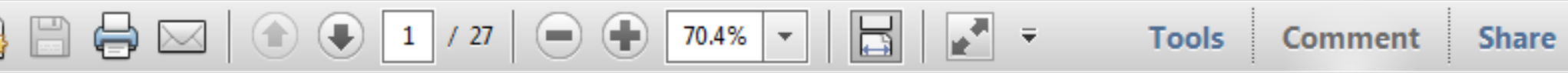

This will open up a panel down the right side of the document. The majority of tools you will use for annotating your proof will be in the Annotations section, pictured opposite. We've picked out some of these tools below:

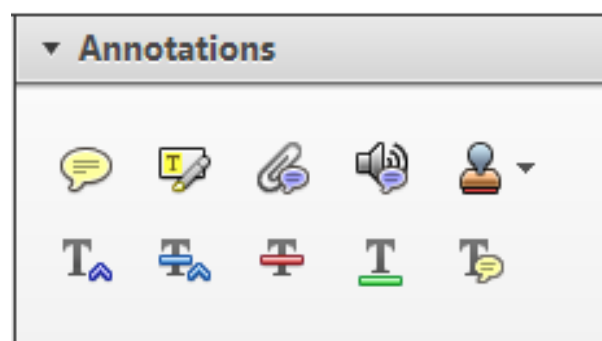

1. Replace (Ins) Tool - for replacing text.

Strikes a line through text and opens up a text box where replacement text can be entered.

How to use it

- Highlight a word or sentence.

- Click on the Replace (Ins) icon in the Annotations section.

- Type the replacement text into the blue box that appears.

Idard tramework for the analysis of $\mathrm{m}$ icy-Nevertheless, it also led to exog،

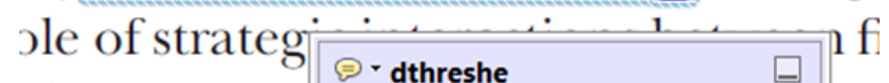
aber of comp 08/06/2011 15:58:17 is that the s1 nain compo: be level, are exc nc

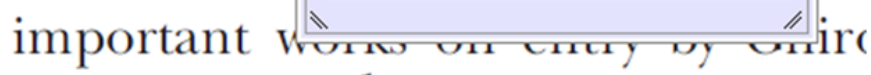
M heneferth) ${ }^{1}$ we anen the "hlarl $\mathrm{l}$

3. Add note to text Tool - for highlighting a section to be changed to bold or italic.

T Highlights text in yellow and opens up a text box where comments can be entered.

\section{How to use it}

- Highlight the relevant section of text.

- Click on the Add note to text icon in the Annotations section.

- Type instruction on what should be changed regarding the text into the yellow box that appears.

namic responses of mark ups ent with the VAR evidence

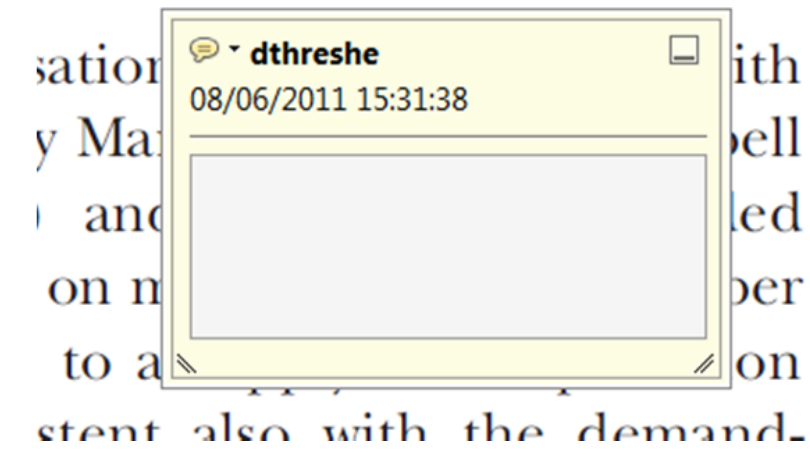

2. Strikethrough (Del) Tool - for deleting text.

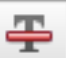

Strikes a red line through text that is to be deleted.

How to use it

- Highlight a word or sentence.

- Click on the Strikethrough (Del) icon in the Annotations section.

there is no room tor extra prohts al c ups are zero and the number of ret) values are not determined by Blanchard and Kiyotaki (1987), sfect competition in general equilil ts of aggregate demand and supply lassical framework assuming monol eph on evorenous number of firme

4. Add sticky note Tool - for making notes at specific points in the text.

Marks a point in the proof where a comment needs to be highlighted.

How to use it

- Click on the Add sticky note icon in the Annotations section.

- Click at the point in the proof where the comment should be inserted.

- Type the comment into the yellow box that appears.

iaisu airu suppiy sirucks. hivsl ui

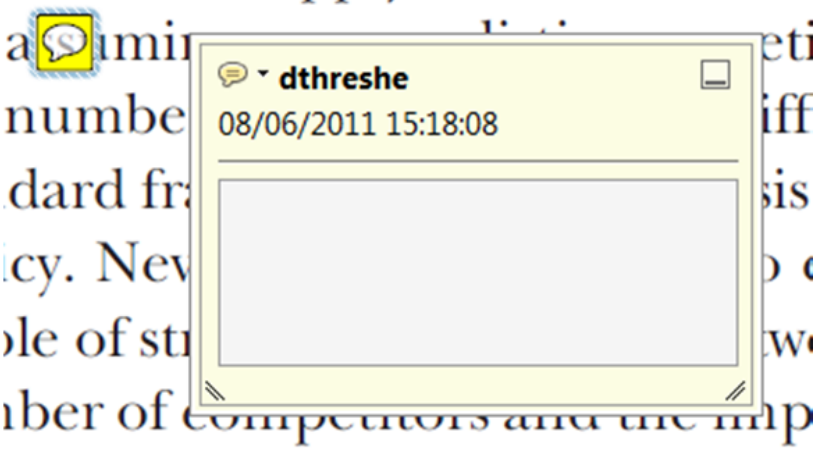

is that the structure of the secto. 
5. Attach File Tool - for inserting large amounts of text or replacement figures.

Inserts an icon linking to the attached file in the appropriate pace in the text.

How to use it

- Click on the Attach File icon in the Annotations section.

- Click on the proof to where you'd like the attached file to be linked.

- Select the file to be attached from your computer or network.

- Select the colour and type of icon that will appear in the proof. Click OK.

E N D

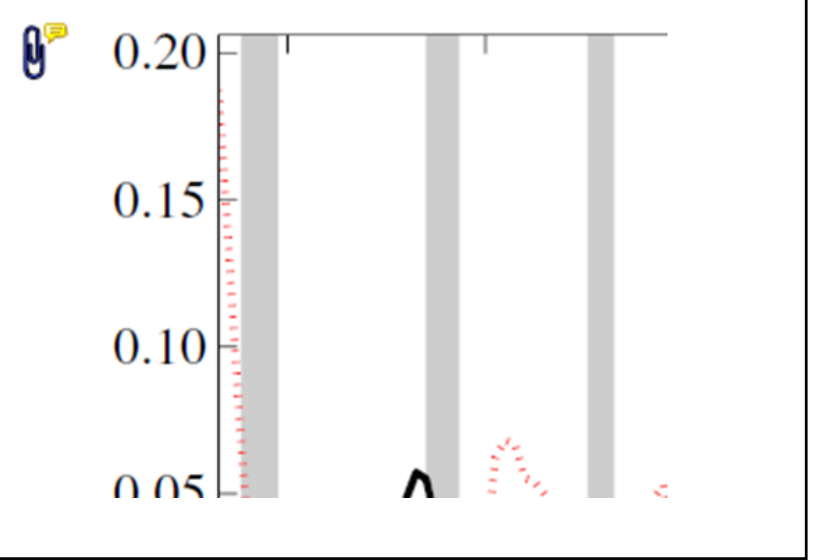

6. Add stamp Tool - for approving a proof if no corrections are required.

- Inserts a selected stamp onto an appropriate place in the proof.

\section{How to use it}

- Click on the Add stamp icon in the Annotations section.

- $\quad$ Select the stamp you want to use. (The Approved stamp is usually available directly in the menu that appears).

- Click on the proof where you'd like the stamp to appear. (Where a proof is to be approved as it is, this would normally be on the first page).

or the business cycie, starting with the on perfect competition, constant ret

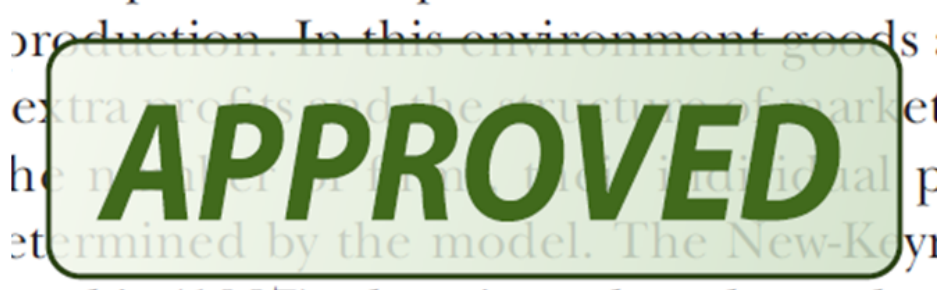
otaki (1987), has introduced produc general equilibrium models with nomin:

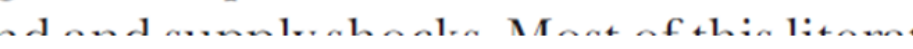

- Drawing Markups

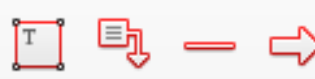

$0 \bigcirc \sqrt{6} \otimes$

\section{How to use it}

- Click on one of the shapes in the Drawing Markups section.

- Click on the proof at the relevant point and draw the selected shape with the cursor.

- To add a comment to the drawn shape, move the cursor over the shape until an arrowhead appears.

- Double click on the shape and type any text in the red box that appears.
7. Drawing Markups Tools - for drawing shapes, lines and freeform annotations on proofs and commenting on these marks.

Allows shapes, lines and freeform annotations to be drawn on proofs and for comment to be made on these marks.

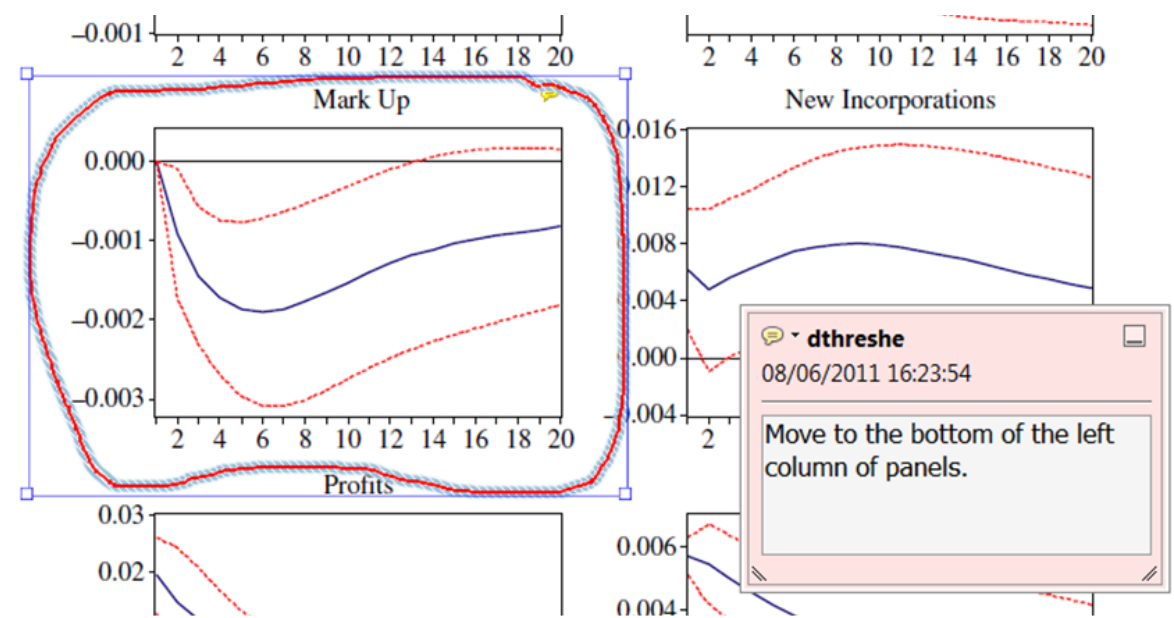

For further information on how to annotate proofs, click on the Help menu to reveal a list of further options:

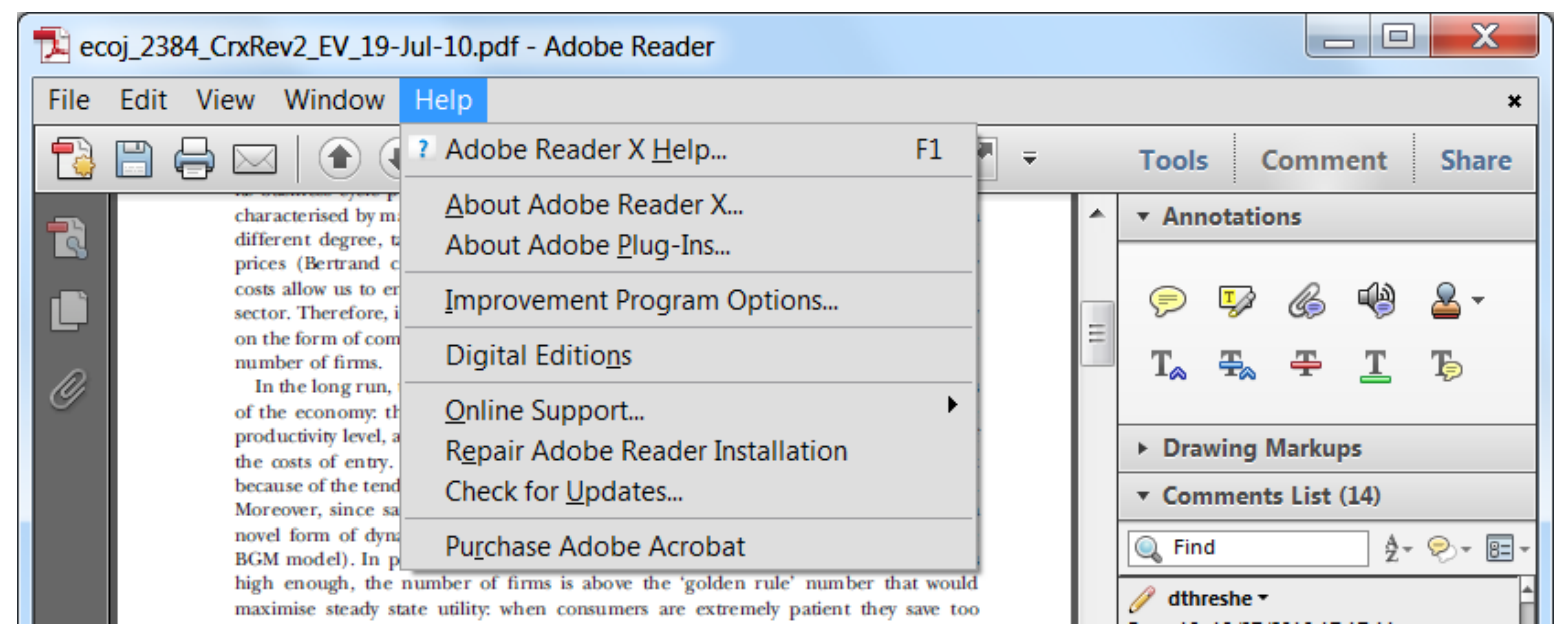

